Cahiers $d u$ MONDE RUSSE

\section{Cahiers du monde russe}

Russie - Empire russe - Union soviétique et États indépendants

$49 / 1 \mid 2008$

Réformes et société en Asie centrale tsariste et soviétique

\title{
Judicial Elections as a Colonial Reform
}

The Qadis and Biys in Tashkent, 1868-1883

\section{Paolo Sartori}

\section{(2) OpenEdition}

\section{Journals}

Édition électronique

URL : https://journals.openedition.org/monderusse/9120

DOI : $10.4000 /$ monderusse. 9120

ISSN : $1777-5388$

Éditeur

Éditions de l'EHESS

Édition imprimée

Date de publication : 25 février 2008

Pagination : $79-100$

ISBN : 978-2-7132-2195-8

ISSN : $1252-6576$

Référence électronique

Paolo Sartori, « Judicial Elections as a Colonial Reform », Cahiers du monde russe [En ligne], 49/1 |

2008, mis en ligne le 01 janvier 2009, consulté le 04 septembre 2022. URL : http://

journals.openedition.org/monderusse/9120 ; DOI : https://doi.org/10.4000/monderusse.9120 
chercher : repérer : avancer

Cet article est disponible en ligne à l'adresse :

http://www.cairn.info/article.php?ID REVUE=CMR\&ID NUMPUBLIE=CMR 491\&ID ARTICLE=CMR 4910079

Judicial Elections as a Colonial Reform. The Qadis and Biys in Tashkent, 1868-1883

par Paolo SARTORI

\section{Editions de l'EHESS | Cahiers du monde russe}

2008/1 - Vol 49

ISSN 1252-6576 | ISBN 9782713221958 | pages 79 à 100

Pour citer cet article :

-Sartori P., Judicial Elections as a Colonial Reform. The Qadis and Biys in Tashkent, 1868-1883, Cahiers du monde russe 2008/1, Vol 49, p. 79-100.

Distribution électronique Cairn pour les Editions de l'EHESS.

(C) Editions de l'EHESS. Tous droits réservés pour tous pays.

La reproduction ou représentation de cet article, notamment par photocopie, n'est autorisée que dans les limites des conditions générales d'utilisation du site ou, le cas échéant, des conditions générales de la licence souscrite par votre établissement. Toute autre reproduction ou représentation, en tout ou partie, sous quelque forme et de quelque manière que ce soit, est interdite sauf accord préalable et écrit de l'éditeur, en dehors des cas prévus par la législation en vigueur en France. Il est précisé que son stockage dans une base de données est également interdit. 


\section{JUDICIAL ELECTIONS AS A COLONIAL REFORM}

\section{The Qadis and Biys in Tashkent, 1868-18831}

The expansion of the Russian Empire in the nineteenth century was followed by the incorporation of new bodies of law into the state judicial system. Instead of imposing Russian legal institutions, state policy was to support a pluralistic legal regime ("a cheap way to keep the peace - in return for tribute and taxes"). ${ }^{2}$ As the Empire extended its boundaries and moved into new territories, gaining control over their resources, Russian lawmakers and administrators had to impose governance and secure social order in the regions being incorporated into the state system. Thus, encompassing local bodies of law into the Imperial governance, as well as recognizing rights and obligations in accordance with indigenous customs and laws were seen as necessary tools for implementing Imperial policies of colonization.

There is no reason to doubt that the establishment of Russian rule in Central Asia was shaped by this policy. When lawmakers discussed the first draft of the enactment designed for governing Turkestan, they were concerned that the new province would be a burden on the Imperial treasury. ${ }^{3}$ In addition they felt that allowing the indigenous inhabitants to continue to exercise some control over legal

1. This study was done as part of the research project "Islamic Law in Central Asia Under Tsarist and Early Soviet Rule: Tashkent Qadi-Courts from 1865 to 1928 " funded by the Volkswagen Stiftung. I would like to thank Ulfatbek Abdurasulov, Hamidulla Aminov, Ghulom Karimov and Shovosil Ziyodov for their valuable assistance during this research. I am also grateful to Wolfgang Holzwarth, Alexander Morrison, Jürgen Paul, and two anonymous referees for Cahiers du Monde russe for their insightful comments on earlier drafts.

2. Jane Burbank, "An Imperial Rights Regime. Law and Citizenship in the Russian Empire," Kritika. Explorations in Russian and Eurasian History, 7, 3 (2006): 402.

3. "Po povodu mestnoi administratsii Turkestanskoi oblasti," Turkestanskii sbornik, tom VI, sostavliaemyi V.I. Mezhovym (SPb., 1860), 275. 
proceedings and also exercise the right to appeal to Imperial courts would be a good way to spread the Russian understanding of civil society (grazhdanstvennost') among the local population. ${ }^{4}$

From the legislators' point of view, the incorporation of local systems of law was formalized in accordance with the idea of reform. Indeed, "reforms" was the key word used by Russian officers and administrators when they drew up regulations to make the exercise of indigenous law more efficient and see to it that the legal practice of local communities complied with Imperial standards. 5

Recent scholarship has not disregarded the importance of these issues, but attention focused on colonial regulations while the legal features and the limits of the "reforming" policy on the Central Asian judicature went largely unquestioned. ${ }^{6}$ Therefore, what these "reforms" consisted of and the results that ensued from them are questions which still await systematic investigation.

From the following discussion it will be clear that Russians succeeded in reforming only the office of judge of Islamic and customary law (respectively shar 'at- and 'a $\bar{a}$ dat-based) courts. Thus, if we want to assess the effect of tsarist colonial policy on the field of law in Turkestan, we should look primarily at the impact the reform had on the career of the indigenous judiciary. For this purpose, this paper will focus on elections for the offices of qadi $^{7}$ and biy. In this respect, colonial Tashkent is an ideal environment on which to concentrate our investigation: it had a large number of native judges as there were four shar 'at-based courts and one that was ' $\bar{a}$ dat-based. Moreover, it was the capital city of the general governorship, thus expected by its Russian administrators to serve as an example of the good effects of their policies of colonization. ${ }^{8}$ As for the time span this study should cover, we have decided to examine some micro-stories between the years 1867 and 1883 . This period roughly corresponds with the implementation of the 1867 Provisional Statute, ${ }^{9}$ the

4. Ibid., 277.

5. N. Frideriks, “Turkestan i ego reformy,” Vestnik Evropy, 6 (1869): 691-712.

6. To the best of our knowledge, the issue of judicial reform in Central Asia has been studied only by Ol'ga I. Brusina, "Obychnoe pravo kochevogo naseleniia Turkestana v sisteme rossiiskogo upravleniia," in Sergei N. Abashin and Vladimir I. Bushkov, eds., Sredneaziatskii sbornik, 5, (2006): 217-234. A German translation is also available as "Die Transformation der Adat-Gerichte bei den Nomaden Turkestans in der zweiten Hälften des 19. Jahrhunderts," in Michael Kemper and Maurus Reinkowski, eds., Rechtspluralismus in der Islamischen Welt, (Berlin and New York: De Gruyter, 2005), 227-253. This article was reviewed by Virginia Martin, but disappointingly the theme of judicial reform was not directly discussed, cf. Central Eurasian Reader, 1 (2008): 240241. In another work, Law and Custom in the Steppe. The Kazakhs of the Middle Horde and Russian Colonialism in the Nineteenth Century (Surrey UK: Curzon, 2001), 50-51, Martin does mention judicial reforms in Russian Turkestan but without investigating them in depth.

7. In the original Arabic-script sources, the word is spelled as $q \bar{a} z \bar{\imath}$.

8. Proekt vsepoddanneishago otcheta Gen. Ad"iutanta N.P. fon-Kaufmana po grazhdanskomu upravleniiu $i$ ustroistvu $v$ oblastyakh turkestan general-gubernatorstva ( $\mathrm{SPb}$.: Voennaia Tipografiia, 1885), 50.

9. "Proekt polozheniia ob upravlenii semirechenskoi i syr-dar'inskoi oblastei," in Materialy po istorii politicheskogo stroia Kazakhstana (so vremeni prisoedineniia Kazakhstana k Rossii do velikoi oktiabr'skoi sotsialisticheskoi revoliutsii), t. 1 (Alma-Ata: Izdatel'stvo Akademii nauk 
moment when local communities were first confronted with the enforcement of the new regulations concerning the judiciary. From this perspective, exploring this period will allow us to trace the way indigenous groups initially coped with the new rules.

\section{The Scope of "Reform"}

Colonial "reforms" involved the local judicature mainly at a macro-level: the enactment introduced by the Russian government in Turkestan in 1867 changed the procedure for selecting court officials as the statute granted local communities the right to elect their own judges. In addition, shart' ${ }^{\prime} a t$ - and 'a dat-based courts were deprived of authority over criminal law and could hear only a limited number of cases. ${ }^{10}$ Russians also intervened in the way justice was to be administered: punishments were commuted into sanctions and brought into line with Imperial law, thus forbidding the death penalty and stoning. ${ }^{11}$

Conversely, legal practice - the micro-level of the judicature - was almost completely disregarded by the Russians and thus left outside of the realm of the "reforms." This does not come as a surprise as the basic approach to reforming the local judicial systems was fully congruous with the oft-quoted strategy of noninterference (ignorirovanie) designed by the first governor-general, von Kaufman. The arguments usually given to explain this policy are twofold: on the one hand, at the beginning of their colonial enterprise, the Russians had a cautious approach towards Islam and Muslim customs, as they did not want to stir up local feelings of discontent. On the other hand, the newcomers claimed that in the long run introducing new legal practices and integrating them with existing ones would compel the indigenous population to lose respect for local courts and choose the more civilized Imperial tribunals. ${ }^{12}$

However, the Russians' reluctance to interfere with existing legal practice should not only be interpreted as a result of the interaction of cautiousness and civilizing superiority. ${ }^{13}$ What should instead be emphasized are the principles which guided the way colonial enactments on matters regarding the legal sphere

Kazakhskoi SSR, 1969). When referring to entries of the Provisional Statute, we will use the symbol .

10. On this point see Martin, op. cit., 92. However, it should be noted that qadis continued to hear cases of robbery even if these were formally under the jurisdiction of the Imperial judiciary. Cf., for example, the following files in the Sībzār qadi-court register for the year 1899: TsGARUz (Tsentral'nyi Gosudarstvennyi Arkhiv Respubliki Uzbekistan - Central State Archive of the Republic of Uzbekistan), f. I-365, op. 1, d. 74, 1. 45, 77, 83, 117, 149, 155.

11. Martin, op. cit., 52-53.

12. G. Zagriazhskii, "O narodnom sude u kochevago naseleniia Turkestanskago kraia, po obychnomu pravu (zan)," in Materialy dlia statistiki Turkestanskago kraia. Ezhegodnik pod redaktsiei N.A. Maeva, vypusk IV (SPb., 1876), 191; I.I. Kraft, Sudebnaia chast' $v$ Turkestanskom krae i v stepnykh oblastiakh (Orenburg: tipo litografiia N.N. Zharilova, 1898), 92.

13. On this last point see the valuable observations of Martin, op. cit., 48. 
were drawn up. The basic guidelines for the reorganization of the judiciary in Central Asia under the umbrella of Russian rule are to be found in the judicial reform signed by Alexander II in 1864, which called for avoiding arbitrariness, thus allowing oral argumentations and the holding of public trials. But what Russian administrators sought to introduce immediately in the Central Asian legal environment was the idea that judges should be independent, thus be elected by their peers..$^{14}$

There is a further reason why colonial interference with the indigenous legal systems was restricted to the macro-level. When the colonial government was established in the region, Imperial legal ethnography had already been developed and descriptions of court proceedings had been collected in articles and books. ${ }^{15}$ However, the cumulative experience of Imperial administrators, ethnographers, and statisticians gathered in these publications was of little value to Russian lawmakers in terms of administrative and legal usefulness. In fact, besides a large number of articles of an introductory nature, administrators, scholars, and statistical committees had compiled codes, or else collected and described legal cases following a custom already well established in the Northern Caucasus. ${ }^{16}$ However, for the colonial officers asked to assess the soundness of the legal practice of shar ' 'at- and 'âdat-based courts this accumulation of knowledge was of little use. Referring to either a code or to a collection of cases, it is unlikely that without proper legal training, Russian officers would sit in on biy-court hearings or interfere directly with legal proceedings. ${ }^{17}$ Moreover, even if they were able to understand the court hearings - as some administrators in the late period of tsarist rule most probably were - it did not imply that colonial officers could influence qadis' and biys' legal understanding, nor change the way they resorted to traditional legal mechanisms or issued legal certificates. ${ }^{18}$ This is why, with the sole exception of the attempt made by Count Pahlen at the beginning of the twentieth century, the

14. All these points have been carefully studied by Jörg Baberowski, "Law, the Judicial System, and the Legal Profession," The Cambridge History of Russia. Vol. 2, Imperial Russia, 1689-1917, Dominic Lieven, ed., (Cambridge: Cambridge University Press, 2006), 344-368.

15. To date, the most comprehensive list of such publications was compiled by Virginia Martin, op. cit., 164-165, notes 9-13. The argument on the importance of cumulative colonial knowledge of the local judicature, however, holds true only for biy-courts, but not for those presided over by qadis', as studies on Islamic law in Central Asia appeared rather late, only after 1892.

16. Michal Kemper, "Adat Against Shari'a: Russian Approaches towards Daghestani 'Customary Law' in the 19th Century," in Bairam Balci and Raoul Motika, eds., Religion et Politique dans le Caucase Post-Soviétique, (P.: Maisonneuve \& Larose, 2007), 74-95.

17. This point was first set out in Kirgizskaia stepnaia gazeta. Chelovek, obshchestvo, priroda 1888-1902, sostavitel' U. Subkhanberdina (Amaty: Gylim, 1994), 558 and later discussed by A.A. Divaev, "K voprosu o kirgizkikh sudakh," Okraina, no. 102 (1897).

18. However, this does not mean that new kinds of legal documents did not appear after Russian colonization. As the Russians attempted to build a cadastral archive, qadis were asked to produce certificates of testimonies (guwāhnāma) in Turki which testified the soundness of purchase and sale of land. It goes without saying that analogous documents had not been produced before, as it seems that the khanates and the emirates did not have a cadastral register. 
codification of Central Asian legal systems was never conceived as an interface between the colonial state and the local society. The reason this happened is that contrary to British officers in India, Russians did not want to take the place of indigenous judges. ${ }^{19}$ Therefore, we cannot but agree with Virginia Martin when she describes the introduction of the colonial statutes as "a failure of codification." 20 This is the reason why, even though local legal practice was known to the Russians administering Turkestan, they did not see it as being subject to reform.

\section{Elections for the Local Administration}

The 1867 Provisional Statute officially introduced voting for two administrative offices. As far as the settled population was concerned, the colonial enactment ruled that administrators with police and fiscal duties (aksakals), ${ }^{21}$ and judiciaries (qadis) would be elected every three years..$^{22}$ The system, however, was not based on direct voting. Only the ellikboshi, ${ }^{23}$ the representatives of 50 households in the communities in every defined area of settlement, such as a city district or a village, cast a ballot. ${ }^{24}$ In the same way, nomads could elect administrators with the same duties as the aksakals ${ }^{25}$ at the volost' and aul levels, ${ }^{26}$ as well as the judiciaries (biys) for 'adat-based courts. ${ }^{27}$ In order to become effective, the result of such elections had to be confirmed by the colonial authority.

Why did the Russians introduce a norm of this sort? As it appeared only a few years after the Great Reforms, one is tempted to interpret the policy in relation to the creation of the zemstvo in Western Russia. ${ }^{28}$ As in the Volga-Ural regions and Siberia all the estates of a given community were granted the right to elect a local

19. On this point see Alan K. Scott, "Framed, Blamed and Renamed: The Recasting of Islamic Jurisprudence in Colonial South Asia," Modern Asian Studies, 35, 2 (May, 2001): 257-313.

20. Martin, op. cit., 51

21. In Turki sources $\bar{a} q s a q \bar{a} l$, or $m \bar{\imath} n g b \bar{a} s h \bar{l}$.

22. "Proekt polozheniia...," art. cit., § 118, 217.

23. In Turki and Russian the term was respectively spelled as $\bar{l} l 1 \bar{l} k b \bar{a} s h \bar{\imath}$ and piatidesiatnik.

24. "Proekt polozheniia...," art. cit., § 119.

25. Ibid., $\$ 125$.

26. Ibid., $\$ 85-97$.

27. It goes without saying that the administrative subdivision of territories inhabited by nomads was different compared to settled areas: the size of an aul - the basic administrative unit of a nomadic area - is not directly comparable to that of a village (kishlak) or a city district (kvartal). For more information on the proportions and the procedures adopted in elections of volost' governors and biys, see Zhanar Dzhampeisova, Kazakhskoe obshchestvo i pravo $v$ poreformennoi stepi (Astana: ENU im. L.N. Gumileva, 2006), 164 and passim.

28. On this issue see Aleksei Volvenko, "The Zemstvo Reform, the Cossacks, and Administrative Policy on the Don, 1864-1882," in J. Burbank, M. von Hagen, A. Remnev, eds., Russian Empire. Space, People, Power, 1700-1930, (Bloomington and Indianapolis: Indiana University Press, 2007), 348-365. 
government, ${ }^{29}$ so the Muslims of Central Asia were allowed to create organs of self-administration (samoupravlenie) on the basis of democratic principles. ${ }^{30}$ However, in addition to expressing the colonial government's desire to spread enlightened social ideas, the introduction of the new regulation was pragmatic. As the Russians did not know the indigenous population and feared the traditional patronage system of the khans, they hoped that if granted the right to vote, the locals would choose the most respectable person among their peers (bolee pochitaemoe litso), a person whose moral virtues would also guarantee he would be skilled in administrative work. Consequently colonial officers could avoid the risk of choosing the wrong person as this was no longer their responsibility. ${ }^{31}$

For Turkestani Muslims, electing their own administrators was a true reform, a real change from the past. In fact, in precolonial times the centralized administration of the khanates used to appoint its representatives ('amaldār), even at the village level. The appointment to a certain administrative position was conceived as a means to establish reciprocity between the state and its representatives based on an exchange of favors: if an administrator proved to be loyal to the state, he would enjoy certain advantages, the most common being tax exemption..$^{32}$ This meant that behind an appointment made by the local ruler or representatives of the state there were often factions lobbying for an official administrative position. In fact, as endorsement from a local governor usually involved fiscal privileges, it is likely that these benefits were redistributed among the group who supported a candidature. This is why, for example, under the Bukharan emirs someone could be appointed to the post of aksakal after being officially endorsed by local notables. ${ }^{33}$

The introduction of the electoral process among the Muslim population of Tashkent initially met with resistance from the scholars ('ulam $\bar{a}$ '). At the beginning

29. It is perhaps worth recalling that Muslims under the authority of the Orenburg Muslim Spiritual Administration were represented in the Siberian zemstva, while such institutions were never established in Central Asia. On this issue see Norihiro Naganawa, "Molding the Muslim Community through the Tsarist Administration: Mahalla under the Jurisdiction of the Orenburg Mohammedan Spiritual Assembly after 1905," Acta Slavica Iaponica, 23 (2006): 101-123.

30. N. Mordvinov, “Administratsiia u osedlikh inorodtsev Turkestana," Russkii Vestnik, (iiun' 1899): 330 .

31. Ershov, "Neskol’ko slov o vyborakh,” Turkestanskie Vedomosti, 75 (1908): 105.

32. R.N. Nabiev, Iz istorii kokandskogo khanstva (Feodal'noe khoziaistvo Khudoiar-Khana) (Tashkent: FAN, 1973), 242 and passim. It should be noted that such fiscal privileges could be bestowed as a tarkhān status granting immunity mainly "to religious figures such as prominent Sufi or members of sacred lineages," William Wood, A Collection of Tarkhan Yarliqs from the Khanate of Khiva, Papers on Inner Asia, $n^{\circ} 38$ (Bloomington: Indiana University, 2005), 2930. This also holds true for other regions of precolonial Central Asia, such as the Ferghana Valley, cf. A. Juvonmardiev, XVI-XIX asrlarda Farghonada er-suv masalalariga doir (Tashkent: FAN, 1965), documents no. 18/42, 105/71, 6/81. It is worth recalling that a state appointment to official duties did not ipso facto imply the privileges described.

33. This is a copy of a document of endorsement for the position of aksakal (khatt-i $\bar{a} q s a q \bar{a} l \bar{l}$ ) for the district ( $t \bar{u} m \bar{a} \bar{n})$ of Tushmak originally made in 1301/1883-4, cf. Munsha' āt-i Mirzā Bahādir Khwāja b. Husayn Khwāja-i Pīrmastī, ms. Tashkent, Institute of Oriental Studies, Academy of Sciences, inv. no. 2667, f. $125^{\mathrm{v}}$. 
of 1868 , the colonial establishment set up a special commission whose task was to explain the main issues of the Provisional Statute to the locals. ${ }^{34}$ Forty individuals, including scholars and notables, had the possibility to openly discuss colonial polity with Russian officials and raise questions regarding its implementation. When the commission touched upon the issue of the election of the judiciary, some 'ulamā' held that it would be contrary to the shar' 'at. Paving the way for future collaboration in the realm of Islamic jurisprudence, the special commission asked that the 'ulam $\bar{a}$ ' resolve the question in accordance with Islamic law. Accordingly, some of them resorted to a collection of legal opinions (fatāwā) called Fusūl al'Imā $\bar{d}{ }^{35}$ Quoting a passage in a chapter on qadis, they issued an authoritative opinion which held that notwithstanding the fact that the governor was not a Muslim, the Muslim community had the right to endorse his qadi: the condition was that the Muslims had to gather and express agreement on the person to choose. ${ }^{36}$

As we noted above, the ellikboshis were the individuals immediately responsible for the functioning of the election system. For example, in Tashkent the ellikboshis of each of the four city districts had to gather and elect one qadi and six aksakals. One of them would have police duties while the other five would become members of the Economic Administration ${ }^{37}$ of the city, which was the institution set up to levy taxes from the indigenous population. ${ }^{38}$ In addition, the Russian administration opted for elections as the means for choosing functionaries to oversee irrigation (arigh-aksakals) ${ }^{39}$ and those who would serve as assistants to each aksakal. ${ }^{40}$

In the years following the first elections, Muslims in Tashkent used the same procedure to choose individuals for a wide variety of positions with social significance. In 1872, the shopkeepers (dukāndār) of the main bazaar in the

34. F. Azadaev, Tashkent vo vtoroi polovine XIX veka. Ocherki sotsial'no-ekonomicheskoi $i$ politicheskoi istorii, Tashkent: Izdatel’stvo Akademii Nauk Uzbekskoi SSR, 1959), 96.

35. It is a work also known as Fusūl al-ahkām fi usūl al-ahkām, compiled in Samarkand in 621/ 1253 by Abū al-Fath Zayn al-Dīn b. a. Bakr 'Imād al-Dīn b. 'Alī b. a. Bakr (d. after 670/12712), cf. Carl Brockelmann, Geschichte der arabischen Literatur, zweite Auflage, S 1, (Leiden, New York, Köln: Brill, 1996), 656. It was a text widely used by Muslim jurists in Central Asia, and extensively quoted in the opinions given by the jurists as well as in the lists of books left by local scholars, cf. Asāmī̄i kitābhāy-i mawjūda ba dast-i faq̄̄r az manqūlāt-i bahr al-manāfiq, ms. Samarkand, State Museum of History, Art and Archeology, inv. no. 4089/9, f. 3r . The list bears the seal of Mullā Abū al-Qāsim Muftī, which is dated 1322/1904-5. See also N.P. Ostroumov, Islamovedenie. Shariat po shkole (mazkhab) Abu-Khanify (Tashkent: Tip. Pri. Kants. Turk. Gen.-Gub., 1912), 17.

36. TsGARUz, f. I-36, op. 16, d. 66, 1. 7-6. This is a trilingual document in Arabic, Persian and Turki.

37. The Russian and Turki terms to denote the institution were respectively khoziaistvennoe upravlenie and dūma. It is perhaps worth noting that the Muslims "Turkified" the Russian term duma, which at that time stood for "municipality."

38. "Proekt polozheniia...," art. cit., § 245-248.

39. In Turki ar̄̄gh-āqsāqāl, mīrāab.

40. The minutes of the election of all the indigenous administration of Tashkent can be found in Zhurnaly zasedaniia tashkentskoi organizatsionnoi komissii, TsGARUz, F. I-36, op. 16, d. 66, 11. 12-86ob. 
Russian part of Tashkent submitted a petition to City Commandant Pukalov asking him to let them elect a new aksakal after the death of the old one. ${ }^{41}$ Similarly, the wood sellers (yaghāch-furūsh) working in the Tashkent market (iarmarka), asked the Russian administration to confirm the election of their aksakal. ${ }^{42}$ Having an aksakal for each bazaar guild was in line with local tradition. ${ }^{43}$ But electing the madrasa staff was certainly something new: in the same year, the mullahs of the Khwāja Ahrār Madrasa, relying on the support of the ellikboshis and the notables $(y \bar{u} r t-y \bar{a} k h s h \bar{l} l \bar{a} r \bar{\imath})$ of the district in which the building was located (Sibzar), submitted to the city commandant a request for permission to elect a new mudarris from among the faculty of the institute. ${ }^{44}$

Within a few years, the election procedure became an instrument local communities could use to take over the administration of mosques, madrasas and charitable endowments (waqf). As the understaffed colonial administration could not closely control every election, it was easy for local groups to persuade the Russians of the necessity of new appointments. Such procedures usually involved two steps: a petition from a given community and a document stating that the electors agreed to choose one individual from among their fellow citizens. For example in 1873 the ellikboshis and the population of the mahalla Sakichman in the Kukcha district protested against the inadequacy of the mullahs and the teachers (mudarris) of the Būrī Ishān Khwāja Madrasa and asked City Commandant Medinskii to confirm the appointment of Mullā Muhammad Zūnnūn to the post of mudarris. ${ }^{45}$ Along with the petition, the Russian officers received a "document of election" (sāylāw khatt) with the signatures of all the mullahs of the mosque, stating that they had decided on this course of action on the basis of an agreement (ittifā $\bar{\imath} l \bar{a} n) .{ }^{46}$ The same thing happened with the Īshān Qūlī Dādkhwāh Madrasa:

41. 'Arz-nāma. Tāshkand shahr-n̄̄ Pūlakuwch̄̄ hākim-mīzgha piyān bāzārinda, TsGARUz, f. I-36, op. 1, d.641, 1.45. The original was then translated into Russian as Proshenie torgovogo obshchestva voskresenskogo bazara, TsGARUz, f. I-36, op. 1, d. 641, 1. 38-38ob. It is perhaps worth noting that the original petition in Arabic script addresses the bazaar with the word piyān, which is the turkified form of the Russians term p'ianyi used to denote the voskresenskii bazar. On the bazaar see A.I. Dobrosmyslov, Tashkent $v$ proshlom $i$ nastoiashchem. Istoricheskii ocherk, vypusk vtoroi (Tashkent: Tip. Portseva, 1911), 182-183.

42. 1872-nchī yilda 7nchī sintabrda hurmatlū Tāshkand hākimīgha, TsGARUz, f. I-36, op. 1, d. $641,1.48$. For the document which confirms the election of the aksakals for the wood sellers on the grounds that they represent a considerable number of sarts within the Russian part of the city, see TsGARUz, f. I-36, op. 1, d. 641,1. 50.

43. Nabiev, op. cit., 240-241.

44. 'Izzatlū hurmatlū ūlūgh martabalū Tāshkand hākimīgā, TsGARUz, f. I-36, op. 1, d. 641, 1. 45-45ob. Apparently the petition was successful, as the Russian administration soon received a document with the results of the elections. The mullahs had elected Mullā Muhammad 'Azīm Khān, a qadi in the Beshagach district, as the new mudarris, cf. TsGARUz, f. I-36, op. 1, d. $641,1.55-56$.

45. 1872-nchī yilda 27nchī dīkābrda $\bar{u} l \bar{u} g h$ martabalū Tāshkand hākimī pūlkūfnīk Mìdīnīskī khizmatlārīgha, TsGARUz, f. I-36, op. 2, d. 883, 1. 4-4ob.

46. Sāylāw khatt 1873nchī yilinda 15nchī ghīnwārda, TsGARUz, f. I-36, op. 2, d. 883, 1. 2ob-3. 
after the death of the mudarris, the mullahs and the teachers acted independently and elected ( $s \bar{a} y l \bar{a} d \bar{u} k)$ a new individual to that post. ${ }^{47}$

\section{Winners and Losers: qadis and aksakals}

The colonial regulation introducing the election procedure for administrative appointments created winners and losers. Newly elected individuals enjoyed economic privileges as well as enhanced moral authority. It is likely, for example, that newly elected teachers were the recipients of their madrasas' tuition fees, while a newly appointed imam would probably profit from the redistribution of the pious donations in cash made to the endowment attached to his mosque..$^{48}$ Conversely, this system excluded many other individuals from access to such sources of income. The most striking example is that of the pious endowments which had been administered by individuals inheriting the duty of administrator (mutawallī) for generations. In Tashkent, for example, the properties willed to the Madrasa of Khwāja Ahrār had been administered by a descendant of the founder of the mortmain, a certain Tūra Khān. The income stemming from the lands donated to the madrasa had been divided into three parts: one was set aside for paying the faculty of the madrasa, one for expenses for its restoration, and one for the family of the mutawalli . After the Russian takeover, the mullahs contended (niz $\bar{a}^{\prime} q \bar{l} \bar{l} b$ ) that the administrator was not entitled to take the part of the money due to his offspring as he was alone, and elected one of their own relatives to the post of administrator. Tūra Khān found himself deprived of his salary and had to sell some of his property. ${ }^{49}$

Abandoning the system of patronage in force under the khanate's administration sharpened existing factionalism and stirred up open confrontation between local groups. One of the most telling examples is the election to the post of imam of the mosque of the Sarkhamdan mahalla in Tashkent..$^{50}$ Dissatisfied with their imam, the majority of the people of the district (aksar-i qawm wa ahālì) elected a new one, Muhammad Rasūl Khwāja, known to be a man of learning. But then a minority group (aqall az ān qawm wa ahālī) complained that they wanted to elect another person. The strife between the two factions ended with a lawsuit filed with the Russian administration. ${ }^{51}$

47. 'Izzatlū hurmatlū $\bar{u} l \bar{u} g h$ martabalū Tāshkand hākimīgā, TsGARuz, f. I-36, op. 1, d. 1588, 1. 1 -1ob.

48. The most recent discussion of this subject is to be found in El'ër Karimov, Regesty kaziiskikh dokumentov i khanskikh iarlikov khivinskogo khanstva XVII - nachala XX V. (Tashkent: FAN, 2007), 25-28.

49. Siz ūlūgh martabat-lū afzaliyyat-panāhgha Tāskandlīk B̄̄sh-Yaghāch dahasīda tūrghuwch̄̄ Tūra Khān Tūra Jān-ūghlì Khwāja Ahrār awlādlārīdīn 'arz-nāma, TsGARUz, f. I-164, op. 1, d. $39,1.1$.

50. The account is in TsGARuz, f. I-36, op.1, d. 883,1. 6-6ob.

51. Dar mas'ala ki aksar-i qawm wa ahālī-i mahalla sarkhamdān az mahallāt-i mashhūra-i balda-i Tāshkand, cf. TsGARUz, f. I-36, op. 1, d. 883,1. 7. 
The most and least profitable administrative positions open to the indigenous settled population were respectively those of tax collector and judge - aksakal and qadi. The 1867 Provisional Statute made no provision for paying qadis a salary, nor did it allow them to receive payment from the claimants and defendants in the cases they heard, while it stated that the aksakals' salary was to be decided publicly during elections (\$121). When the regulations of the Provisional Statute were explained to the Tashkent Muslim notables and scholars, the Russians made clear that the basic salary would be 300 rubles per year. ${ }^{52}$ The first evidence we have of the implementation of the regulations in Tashkent is a document produced just some days after this discussion on the Provisional Statute. In this case, the ellikboshis gathered in order to decide the salaries of native-born administrators:

On 19 March 1868 we, the representatives of each and every of the 50 households of the Shaykhantahur district of the City of Tashkent, agreed to sign and seal [the present certificate as] some chief administrators had been elected and appointed. Every year our newly elected aksakal and his assistants will receive 375 rubles, while the arigh-aksakal and his assistants will receive 300 rubles from the aforementioned district in accordance with the economic council. The aksakal, the arigh-aksakal and their assistants will not oversee any volost ${ }^{\prime}$. Our qadi will receive a fee only for marriages. In good faith we signed and affixed our seal to attest to the soundness [of the certificate]..$^{53}$

From the content of this document, it is evident that tax collectors in fact received a yearly salary, the amount of which was far higher than the fees the Islamic judiciary could ever hope to be paid. ${ }^{54}$ However, the aksakals' duties made their position much more at risk than that of the qadis. Apparently, levying taxes in the name of the White Tsar was conceived by Muslims in a different way than ruling in the name of God's law. The Russians knew that taxation was a sensitive issue, especially in Turkestan, and for this reason Tashkent Muslims had been officially ordered to address all their claims (zhaloby) to the chancellery of the city commandant on issues regarding malpractice by aksakals. 55

It was not long before the colonial administration began to receive petitions complaining of injustice. At the beginning of November 1868, in response to the

52. Zhurnaly zasedaniia tashkentskoi organizatsionnoi komissii 1868 g. ianvaria 24 dnia, TsGARUz, f. I-36, op. 16, d. 66,1. 2.

53. Sana bir mīng $\bar{l} k k \bar{l}$ yūz saksān tūrt zū al-qa ‘da, TsGARUz, f. I-164, op. 1, d. 12,1. 1.

54. It is perhaps worth noting that from 1869 to 1870 the salaries of Tashkent arigh-aksakals fluctuated between 300 and 400 silver rubles, cf. Zav. irrigatsii prav. storony reki Chirchika, TsGARUz, f. I-36, op. 1, d. 634, 1.32-32ob. This information supports the reliability of the certificate issued by the Shaykhantaur ellikboshis.

55. Zhiteli vsegda mogut i obiazany obrashchatsia so svoimi zhalobami k nachal'niku goroda. This is how the special commission for the implementation of the 1867 Provisional Statute in Tashkent explained that the Tashkent city commandant would be the recipient of Muslims' appeals, cf. Zhurnal zasedaniia tashkentskoi organizatsionnoi komissii, 1868 g. ianvaria 24 dnia, TsGARUz, f. I-1, op. 16, d. 66, 1. 1ob. 
Russian administration's willingness to investigate complaints concerning wrongdoings by tax collectors and members of the economic council, ${ }^{56}$ the ellikboshis of the Shaykhantaur district accused the arigh-aksakal In'ām Khwāja of having committed illegal actions (sharī'at zakūnīda yūq ìshlārn̄̄ qūladūrghān $b \bar{u} l \bar{u} b) .{ }^{57}$ Nor did it take long for the authorities to act on the complaints. In December 1868, the aksakal of Kukcha was deposed after having been found guilty of corruption. ${ }^{58}$ One year later, the aksakal of Sibzar wrote a letter to the city commandant saying:

Showing my own loyalty and devotion to the [administrative] service, some time ago I revealed the inopportune behavior of swindlers and wrongdoers ( foolish kinsmen (manim nādān aqribālārīm). For this reason, instead of benevolence, I gained many enemies ( $(\bar{u} \bar{s} h m \bar{a} n)$, who, from this time on, using the people's animosity towards me as a pretext, began to defame (yumānlāy) my reputation in front of the government with testimonies of every kind.$^{59}$

As the number of complaints against the aksakals increased, Russian administrators realized that satisfying such demands would contradict the rationale for which they had opted to introduce elections. As early as 1871 they began refusing to respond to such petitions. Russian officers replied that, in so far as tax collectors had been elected by the ellikboshis in their district on the basis of their ability, they were not willing to remove these individuals from office. ${ }^{60}$ Petitions and complaints notwithstanding, elections to the position of aksakal were held regularly every three years. From 1868 until 1880, those chosen underwent a complete reshuffle with every election. ${ }^{61}$

A completely different picture is given by the elections of the qadis. Turnover among the Islamic judiciary in Tashkent during the period of the Provisional Statute was much slower, as demonstrated by a comparison of qadis' registers ${ }^{62}$ with the seals on legal documents in the collection of the Tashkent chief judge. ${ }^{63}$

56. TsGARUz, f. I-36, op. 1, d. 40,1.2.

57. Ibid.

58. The documents concerning this case can be found in TsGARUz, f. I-36, op. 1, d. 37: $O$ vziatochnistve Kukchinskago aksakala Osmana Kariia.

59. Hurmatlū Tāshkand hākimīning lawāzimīn adā qūlghuwchī Tāshkand shahrīnda Sibzār

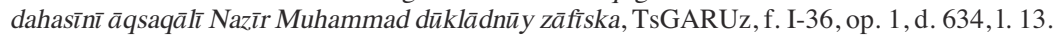
One year later, the aksakal of the Russian bazaar was accused of alcohol abuse and prosecuted, Tashkentskoe politseiskoe upravlenie 23 iiulia 1870 g., TsGARUz, f. I-36, op. 1, d. 642, 1. 12.

60. 4 ianvaria 1871 g. Ego Vysokoblagorodiiu Nachal'niku g. Tashkenta, TsGARUz, f. I-36, op. 1, d. 641, 1. 2-2ob.

61. I compared the documents on the 1874 elections, TsGARUz, f. I-36, op. 1, d. 883, 1. 34-35, with the ones on the activities of the aksakals between 1877 and 1880, TsGARUz, f. I-36, op. 1, d. 1330,1763 .

62. Cf. Tāshkandning qāzūlāri wa shahr siyāz qūzūlārin akt wa hukm daftarlarī̄, TsGARUz, f. I362 , op. 1, d. 59,1.7-22.

63. TsGARUz, f. I-164: Tashkentskii Kazi-Kalian. 
Our method was based on the premise that since according to the Provisional Statute, qadis were provided with a new seal by the Russian administration each time they were elected $(\$ 223),{ }^{64}$ deciphering the seals would allow us to see how many times a given qadi was reelected. In the district of Shaykhantaur the post of qadi was held by Muhammad Sharīf Khwāja b. Pādshāh Khwāja 'Umarī from 1868 to 1889.65 In Sibzar the post of judge remained in the hands of two families from 1868 until 1883. The first to be elected was Muhammad Hakīm Khwāja Īshān, already appointed to the office of Chief Judge (Qāzi Kalān) in 1280/1863 by a decree issued by Mullā 'Alī Qulī ('Alīmqūl), during his rule in Kokand (1863 to 1865). ${ }^{66}$ When he died in $1870,{ }^{67}$ the post was inherited by his son Muhammad Muhiyy al-Dīn Khwāja, ${ }^{68}$ who remained in office until 1882 (thus for four terms of office). He was followed by İshān 'Azīzlār Khwāja, the son of İshān Āy Khwāja Khān, who had previously held the post of Shaykh al-Islām during the last years of the Kokand khanate. ${ }^{69}$ In the district of Kukcha, 'Abdullāh Jān, himself son of a qadi (Bābā Jān), had already been elected to serve as a judge in 1868, and was reelected in $1871^{70}$ and $1874,{ }^{71}$ holding office until 1880 , when the position passed to 'Umar Bīk. ${ }^{72}$ In 1883 the Kukcha ellikboshis elected Mullā Bāy Mīrzā, ${ }^{73}$ while in 1886 they reelected 'Abdullāh Jān..$^{74}$ Only in the district of Beshagach between the

64. The colonial administration provided the Tashkent qadis with seals both in Russian and in Arabic. For the discussion among colonial administrators on the question, see TsGARUz, f. I36 , op. 1, d. 431,1. 15-16.

65. His seals are dated 1871, 1874, 1883 respectively in TsGARUz, f. I-164, op. 1, d. 2, 1. 2; Ibid., d. 6,1. 58; Ibid., d. 6, 1. 8ob.

66. Mulla Muhammad Yunus Djan Shighavul Dadkhah Tashkandi, The Life of 'Alimqul. A Native Chronicle of Nineteenth Century Central Asia, edited and translated by T.K. Beisembiev (London \& New York: Routledge Curzon, 2003), 76.

67. G. Voennomu Gubernatoru Syr-Dar'inskoi oblasti. TsGARUz, f. I-36, op. 1, d. 725, 1. 3.

68. To our knowledge the earliest seal belonging to Muhiyy al-Dīn Khwāja is the one attached to the following document: TsGARUz, f. I-164, op. 1, d. 6,1. 65: Qāzī Muhammad Muhiyy alDīn Khwāja b. Muhammad Hakīm Khwāja Īshān Qāzī Kalān, 1286/1870 - circular, 4 cm, while the latest one was Mullā Muhammad Muhiyy al-Dīn Khwāja Qāzī b. Muhammad Hakīm Khwāja Īshān Qāzī Kalān 'Alaw̄̄, 1304/1886-7 — circular, 4 cm, cf. TsGARUz, f. I-164, op. 1, d. $7,1.21$.

69. Qāzī-i Sibzār 'Az̄̄zlār Khwāja Īshān b. İshān Āy Khwāja Hājjī Shaykh al-Islām, 1300/ 1883 - circular, $4 \mathrm{~cm}$, cf. TsGARUz, f. I-164, op. 1, d. 7, 1.23. The royal patent with the appointment of Īshān Āy Khwāja to the duty of Shaykh al-Islām in 1279/1862-3 is in TsGARUz, f. I-164, op. 1, d. 1,1. 7.

70. Cf. the seal of Qāzī 'Abdullāh Jān b. Qādī Bābā-Jān marhūm, 1288/1871 — circular, 4 cm, in TsGARUz, f. I-164, op. 1, d. 6,1.59.

71. 8/9 aprelia 1874 g.. [...] spisok tuzemtsev, izbrannykh $v$ dolzhnosti na sleduiushee trekhletie, TsGARUz, f. I-36, op. 1.d. 883,1. 3.

72. Cf. the seal of Qāzī Muhammad 'Umar Bīk b. Muhammad Jānī Bīk, 1297/1880 — circular, 4 cm, TsGARUz, f. I-164, op. 1, d. 6,1. 19, 20.

73. Cf. the seal of Qāzì Mullā Bāy Mīrzā b. Mīrzā Āghalīk, 1300/1883-4 - circular, 4 cm, TsGARUz, f. I-164,op. 1, d. 6,1.73.

74. Cf. the seal of Qāzī 'Abdullāh Jān b. Dāmullā Qāzī Kālān Bābā-Jān marhūm, 1304/18867 - circular, 4 cm, TsGARUz, f. I-164, op. 1, d. 6, 1. 76. 
years 1868 and 1886 do we observe any instability, with four different people being elected to the post of judge. Muhammad 'Azīm was elected in 1868 and $1871 .{ }^{75}$ In 1874 the ellikboshis elected 'Ādil Khwāja Īshān but the Russian administration was not pleased with their choice. City Commandant Medinskii was disturbed by the moral authority 'Ādil Khwāja İshān held over the local population and wrote to Military Governor Golovachev that the newly elected qadi might undermine Russian power as he belonged to the social group of the ishans. ${ }^{76} \mathrm{He}$ asked the military governor not to confirm the election, and to appoint Muhammad 'Azīm instead. Probably afraid of arousing popular unrest, the Russian administration tried to collect information from other qadis that would be damaging to Muhammad 'Azīm's reputation, but the jurists answered that they did not know of any wrongdoing he had committed. ${ }^{77}$ Only the ellikboshis complained about him, arguing that nobody from his district had been summoned to the qadis' assembly (mahkama), and that he often intervened in disputes concerning people from the other three districts. ${ }^{78}$ Golovachev was reluctant to choose Muhammad 'Azīm instead of 'Ādil Khwāja Īshān. He did not like either of them, as they were both very influential. Finally, Muhammad 'Azīm himself solved the problem: he wrote to Medinskii to complain that as he had been working as a judge and mudarris since the Russian conquest, his physical condition had worsened (bītāblīk) and his finances had also undergone a decline (yir-suwlārīm mu'attal qālghuw). ${ }^{79}$ Therefore, he asked the city commandant to allow him to resign from the duty of qadi. Accordingly, Golovachev ordered Medinsikii to organize new elections. ${ }^{80}$ This time, Sayyid Bāqī Jān was elected to the judgeship of Beshagach. ${ }^{81} \mathrm{He}$ remained in office until 1883, when he was removed in a blaze of accusations of corruption from the people of his district. ${ }^{82} \mathrm{He}$ was replaced by 'Ādil Khwāja, elected in 1883.83

75. Cf. the seal of Qāzī Muhammad 'Azīm b. Muhammad Rajab, 1287/1871 - circular, 3.6 cm, TsGARUz, f. I-164, op. 1, d. 6, 1. 61 and TsGARUz, f. I-36, op. 1. d. 883, 1. 3.

76. G.nu Voennomu Gunerbatoru syr-dar'inskoi oblasti, TsGARUz, f. I-36, op. 1, d. 883, 1. 30-31ob.

77. 'Izzat wa marhamatlīq wa ulugh martabal̄̄q Tāshkand hākimī pūlkāwnīkgha, TsGARUz, f. I-36, op. 1, d. $883,1.30$.

78. 'Izzatlū wa hurmatlū wa bīk martabalū Tāshkand hākimī Mīdīn-Iskī khizmatlārīgha, TsGARUz, f. I-36, op. 1, d. 883,1. 29.

79. The petition written by Muhammad 'Azīm asking that he be allowed to resign from the office of qadi is in TsGARUz, f. I-36, op. 1, d. 883, 1. 37.

80. Sekretno. 10 iiuniia $1874 \mathrm{~g}$. Voennyj gubernator Syr-Dar'inskoi oblasti nachal'niku g. Tashkenta, TsGARUz, f. I-36, op. 1, d. 883, 1. 46-49.

81. Cf. the seal Qāzī Sayyid Bāqī-Jān b. Abū Qāsim-Khān Īshān 'Alawī, 1291/1874 — circular, 4 cm, TsGARUz, f. I-164, op. 1, d. 7,1. 3 .

82. S zhalobami na Kaziia Seid Baki khana Abdul' Kasym Kan-Ishanova na nespravedlivyi razbor del, vziatki i t.p., TsGARUz, f. I- 36, op. 2, d. 2240.

83. Cf. the seal of Qāzī-i Bīsh Āghāch 'Ādil Khwāja Īshān b. Āftāb Khwāja 'Alawī, 1300/ 1883-4 - circular, $4.2 \mathrm{~cm}$, TsGARUz, f. I-164, op. 1, d. 6,1. 73. 
In short, the introduction of elections did not produce great instability among the qadis of Tashkent. Reelection was common. In this respect, the cases of the judiciary of the Shaykhantaur and Sibzar districts are telling. As far as turnover among the qadis is concerned, it should be kept in mind that in 1883 the individuals serving as judges changed in every district. The most plausible explanation is the major political change that occurred in the colonial administration. GovernorGeneral von Kaufman had died in 1882 and been replaced by Mikhail Cherniaev. The fact that there was a comparably higher degree of instability in the district of Beshagach was mainly due to Russian interference in the election of the qadi in 1874 and the subsequent corruption scandal.

\section{The Kazakhs and their biys in Tashkent}

The indigenous administration of Tashkent did not oversee the rights and obligations of the settled population alone. The town also counted a small Kazakh community of presumably no more than 500 individuals. ${ }^{84}$ Moreover, the city was surrounded by areas which were occupied principally by nomads. Administratively these territories belonged to the Kurama uezd, created in 1871 after the dismantlement of the Jizzakh uezd. ${ }^{85}$ It was not rare to encounter Kazakhs on the city outskirts. While inspecting the city limits in 1868, colonial administrators found a number of Kazakhs (Kirgizy) living outside the city walls. Some of them used the well-irrigated areas around the city as winter pasture (zimovki), ${ }^{86}$ while others were probably semi-nomads who had settled along the rivers Qarasu and Chirchik (southwest of the city) during the winter and said they wished to use the land for agricultural purposes ${ }^{87}$ The most numerous community of Kazakhs was to be found between the Tashkent city limits and the village of Kuyluk, the center of the Kurama uezd. ${ }^{88}$

Until recently it has been argued that in precolonial Central Asia biys - both those acting as clan leaders and those who were judges of customary law courts were chosen by the local nomadic communities on the basis of their moral authority and their knowledge of ' $\bar{a} d a t .{ }^{89}$ This argument has been emphasized to show that the introduction of the election-based system had a negative effect on the practice of ' $\bar{a} d a t$, as it allowed individuals to become biys even if they were not particularly

84. In 1870 Russians statisticians counted 420 Kirghiz, cf. "Prilozhenie № 1. Naselenie SyrDar'inskoi oblasti po plemenam i soslovijam, na osnovanii statisticheskikh svedenii 1870 goda," in Zapiski imperatorskago russkago geograficheskago obshchestva po otdeleniiu statistiki. T. IV, Iu.E. Iansona, red. (SPb., 1874).

85. In 1887 the Kurama uezd was dismantled and these territories were incorporated into the newly established Tashkent uezd.

86. Zhurnal Iv otdeleniia Tashkentskoi organizatsionnoi komissii 15 marta 1868 g., TsGARUz, f. I-1, op. 16, d. 66, 1. 81ob.

87. Ibid., 1. $71 \mathrm{ob}$.

88. Ibid., 1. 94.

89. Martin, op. cit., 26-27. 
knowledgeable about customary law. ${ }^{90}$ Besides the fact that this view reifies an argument that was widespread in periodical literature of the late Tsarist period, ${ }^{91}$ it fails to take into account that not all Central Asian nomadic and tribal groups had been completely independent from the administrations of local rulers and that ' $\bar{a} d a t$ could be the legal system adopted by nomadic and semi-nomadic groups who lived side by side with settled communities under the khanates of the southern territories of Central Asia.

In fact, I contend that in precolonial times, the biys - both as clan leaders and 'a dat-based judiciary - were under the control of the state, and that the holders of these positions had the same status as other notables appointed directly by the khanates' central administration. ${ }^{92}$ Royal patents (yārlīgh) have come down to us which show that there were people appointed to serve as biys for the nomadic population surrounding the main cities of the region..$^{93}$ Moreover, many documents indicate that the biys appointed by the central administration of the Kokand Khanate were granted the same fiscal privileges (e.g. tax exemptions) as other administrative figures such as jurists or state officials, or else allotted a portion of the harvest. ${ }^{94}$

In Tashkent too the appointment of the judiciary for the shar ' 'at- or ' $\bar{a}$ dat-based courts of the city was directly controlled by Kokand. Like qadis and muftis ${ }^{95}$, the biys of the Tashkent Kazakh community were appointed by the governor of Kokand. ${ }^{96}$ However, the analogy notwithstanding, after the Russian conquest and the implementation of the Provisional Statute, the changes in the way biys and qadis were chosen had different outcomes. While the latter could be reelected for more

90. Martin, op. cit., 99 and passim; Brusina, "Obychnoe pravo kochevogo naseleniia Turkestana..." art. cit., 219, 220, 224-5.

91. See for example, "Iz Orenburga," in Vostochnoe obozrenie, 33 (1882), and Kh., "Kirgizskii narodnyi sud," Orenburgskaia gazeta, 53 (1908).

92. P.P. Ivanov, "Ocherki po istorii karakalpakov," in Materialy po istorii karakalpakov. Sbornik. Trudy instituta vostokovedeniia, t. VII (M.-L.: Nauka, 1935), 53. On biy as an official post in the Khivan Khanate's administration, see Dokumenty arkhiva khivinskikh khanov po istorii $i$ etnografii karakalpakov. Podbor dokumentov, vvedenie, perevod, primechaniia i ukazateli Iu.E. Bregelia (M.: Nauka, 1967), 56.

93. See the following patents (yārlīgh) issued in Khiva in the 1830s and 1840s, which appointed biys within the Kazakh tribes in Khorezm, TsGARUz, f. I-125 (Chancellery of the Khivan Khan), op. 2, d. 9, 1. 1; TsGARUz, f. I-125, op. 2, d. 12,1. 1; TsGARUz, f. I-125, op. 2, d. 14,1. 1; TsGARUz, f. I-125, op. 2, d. 15, 1. 4. According to Beisembiev, the biy of QurghanTepa was also appointed by the Kokand administration, cf. The Life of 'Alimqul..., 87.

94. On biys being rewarded or tax exempted by the administration of the Kokand Khanate, see A.L. Troitskaia, Katalog arkhiva kokandskikh khanov XIX veka (M.: Nauka, 1986), documents no. 838-841, 1093, 1290, 1364, 1637, 1640, 1648, 1695. On Kirghiz biys being given official seals by the Kokand rulers see Kyrgyzdar. Sanjyra, tarykh, muras, salt, 2-tom (Bishkek, Kyrgyzstan, 1993), 552-553.

95. Cf. the royal patents in Katalog iz fonda sredneaziatskikh zhalovannykh gramot iz fonda instituta vostokovedeniia im Abu Raikhana Beruni Akademii Nauk Respubliki Uzbekistan, in A. Urunbaev, G. Dzhuraeva, S. Gulomov, sost., Orientwissenschaftliche Hefte, Mitteilungen des SFB/10, 23 (2007), no. 18, 19, 68, 69, 81.

96. S. Soodanbekov, Obshchestvennyi i gosudarstvennyi stroi Kokandskogo khanstva (Bishkek, 2000), 81 . 
than a three-year term of office, the biys were subjected to a great deal of instability because of fluctuations in the support they received from the Kazakh community. This began immediately after the establishment of colonial rule: some months after his election as biy, Mulla Kushuk was accused by members of his own community to the colonial authorities of acting against the Russian government and was consequently removed from his position. ${ }^{97}$ This instability went to such an extent that elections of biys never occurred regularly and were not held simultaneously with the ones for aksakals and qadis, as one would expect. This happened mainly because once elected, the biy was immediately the target of accusations of wrongdoings and illicit behavior. However, such accusations were not grounded on the biys' ignorance of customary law; they originated from a different rationale.

The most telling example of how unstable a biy's position could be is the case of Altybay Qulbay-ughli. His story, as it has come down to us in the archives, begins with a letter of complaint from Kazakhs in Tashkent at the beginning of 1873. The Kazakhs were not dissatisfied with the way he performed his judicial duties, but complained that he had been illicitly levying taxes on them. ${ }^{98}$ In fact, besides holding the post of biy, Altybay claimed to be the fiscal administrator of the Kazakhs of Tashkent, ${ }^{99}$ thus considering himself on a par with a volost' administrator. ${ }^{100}$ Prosecuted by the Imperial court and found guilty, Altybay was attached to the Russian army and sent to Khiva. One year later, in 1874, he returned to Tashkent. Another petition immediately reached the colonial administration: this time, the Kazakhs held that during the previous year their affairs had been satisfactorily overseen by the local aksakals, but that since Altybay had returned to Tashkent, he had been trying to convince Kazakhs to reelect him as their biy. Accordingly, they asked the Tashkent city commandant not to let biy elections be held in Tashkent, as they preferred to move to the Kurama uezd than to be obliged to take back Altybay. ${ }^{101}$ At the end of the same year (1874), the Kazakhs had already changed their minds. Their ellikboshis wrote to the city commandant requesting that he appoint Altybay to his position as biy. ${ }^{102}$ However, the agreement between Altybay and the Kazakh community was not destined to last very long. One and a half years later (July 1876), the city commandant received another petition reporting that in

97. Ob udalenii biia Mully Kushuka iz sredy kochevogo naseleniia za nedobrozhelatel'nost' $k$ russkomu pravitel'stvu, TsGARUz, f. I-36, op. 1.d. 7, 1. 1-7.

98. Zhaloby predsedatelia obshchestva kirgiz na nachal'nika ikh obshchestva po povodu togo, chto poslednii obmannym putem sobiraet s nikh den'gi, TsGARUz, f. I-36, op. 1. d.958, 1. 100 .

99. This claim should not be considered as odd. It is common knowledge that before the colonial rule biys fulfilled, among other duties, that of tax collector, see Dokumenty arkhiva khivinskikh khanov..., op. cit., 30-38 passim.

100. In fact, the Russians filed the letter as "a petition of the Tashkent Kazakhs against Altybay, the volost' administrator," Zhaloby Tashkentskikh kirgiz na volostnogo pravitelia ikh Altybaia, TsGARUz, f. I-36, op. 1, d. 958, 1. 72-73ob.

101. Proshenie Marta 16 dnia 1874, TsGARUz, f. I-36, op. 1, d. 883, 1. 23-23ob.

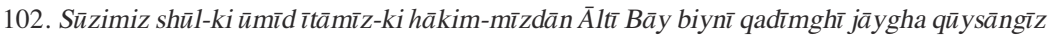
īkān dīb, cf. Tāshkand hākim-mīzgha, TsGARUz, f. I-36, op. 1, d. 883,1. 26. 
1874 the Kazakhs had been ordered to elect a volost' administrator with fiscal duties. Altybay had proposed himself for the office and they had elected him, as "he had promised not to offend us and not to impose illegal taxes." However, now the Kazakhs complained that between 1874 and 1876 Altybay had been collecting yearly taxes from them, plus an annual salary of 300 rubles. ${ }^{103}$

At this point, it is clear that there was a major confusion about the duties Altybay was supposed to carry out: was he a biy or a volost' administrator? The documents addressed to the colonial government by the Kazakh community show that Altybay was elected to both offices. Moreover, if he was only a judge he would not have had the right to claim the 300 rubles, while acting as a volost ${ }^{\prime}$ administrator he would have been entitled to a yearly salary of that kind.

While the Kazakhs' lawsuit was being heard, the city commandant convened an assembly of biys from the Kurama uezd. When questioned, the plaintiffs claimed that Altybay had levied 1140 rubles from 240 Kazakh households. Altybay rejected their accusation. The biys requested that four witnesses take an oath and testify. When no one accepted, the biys "adjudicated the case according to customary law and made the claim void" ( qazāq 'ādat birlān qīlghān da 'Wāning bīkār dīb hukm $q \bar{l}$ lib). ${ }^{104}$ The appeals procedure went on and in 1877 the Russian officers ascertained that in effect Altybay had been assigned a salary of 300 rubles upon the request of the selfsame Kazakhs who had brought the case against him. ${ }^{105}$

By officially holding two positions, Altybay had undoubtedly made enemies: not only did he have the judicial authority to oversee legal cases among the Kazakhs and to levy taxes from them, but he could also claim the right to receive both a salary as an administrator and a fee for every case he heard (biylik). ${ }^{106}$ It is likely that other officers were disturbed by his increasing authority and his favorable financial condition. In fact, Altybay informed the city commandant that the Tashkent aksakals and the Kazakh ellikboshis were jointly orchestrating a machination to vilify his reputation as biy. ${ }^{107}$ Altybay was right. In June, the Kazakhs again petitioned the commandant, saying that they did not want to be judged according to customary law ( 'ârz-dādnì qazāqiyya 'adādīncha sūrāmāqnī

103. 24 iiulia 1876, Ego Vysokoblagorodiiu gospodinu nachal'niku goroda Tashkent, TsGARUz, f. I-36, op. 1, d. 1214,1. 1.

104. 1876nch̄̄ yilda 14nch̄̄ mīzānda Tāshkand hākimīgha qarāghān Qazāq fuqarālār, TsGARUz, f. I-36, op. 1, d. 1214, 1. 3.

105. TsGARUz, f. I-36, op. 1, d. 1214,1. 8-10.

106. Biylik as a fee the biy could charge was officially introduced by the Provisional Statute: it could not exceed $10 \%$ of the value of a disputed property, while in cases of murder and slander it was to be defined in accordance with local customs (soglasno obychaiam), cf. "Proekt polozheniia..." art. cit., § 186. See also N.I. Grodekov, Kirgizy i karakirgizy syr-dar'inskoi oblasti. Tom pervyi. Iuridicheskii byt (SPb., 1885). On cases when biylik was charged arbitrarily see Martin, op. cit., 98. It appears that rather than being a colonial novelty, charging biylik was a well-established practice before the arrival of the Russians, cf. Zagriazhskii, "O narodnom sude u kochevago..." art. cit., 194.

107. 26 ianvaria 1877, Ego Vysokoblagorodiiu gospodinu nachal'niku goroda Tashkent, TsGARUz, f. I-36, op. 1, d. 1214,1. 19. 
munāsīb kūrmāymīz), and, as they lived in Tashkent, they preferred their cases to be adjudicated according to Islamic law (har $\bar{s}$ shìmiz wa yā janjā līmiz būlsa sharı 'at birlān). They also requested that they be put under the jurisdiction of the aksakals. The problem - they claimed - was again Altybay, as his behavior as a biy was

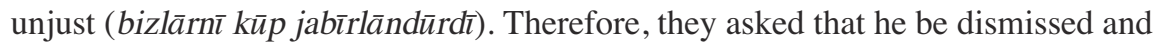
that the rule of shart'at be introduced among them. ${ }^{108}$ At the same time, they repeatedly appealed to the colonial government, namely the city commandant, the general and military governor, calling for the revision of the cases they had previously lost. ${ }^{109}$ The persistence of the Kazakhs paid off: the colonial government was particularly sensitive to the argument that an unqualified person was holding the post of judge. The military governor transmitted the case to the state prosecutor and at the beginning of 1878 , he once again convened an assembly of the Kurama biys, who in three different hearings ruled against Altybay. In order to pay all the debts he had incurred, Altybay was deprived of his entire fortune. ${ }^{110}$

Having learnt a lesson from his fellow Kazakhs, Altybay also presented appeals to the colonial government. He did this twice: in April 1878, he wrote to City Commandant Pukalov ${ }^{111}$ and in May, to Military Governor Trotskii. ${ }^{112}$ In both letters, Altybay claimed to be a victim of injustice. He wrote that in 1876 Kazakh ellikboshis had sued him for 284 rubles and the Kurama biys had prosecuted him but found the claim baseless. Then, even though he had been acquitted, in 1877 the Kazakhs appealed to Governor-General von Kaufman. The latter forwarded the case to his assistant, who examined it and found again that the claim was unfounded. Despite these two rulings in Altybay's favor, the Kazakhs again turned to the colonial administration in February 1878 and, finally, found someone who accepted their appeal and ordered the assembly of Kurama biys to convene and hear the lawsuits. These biys processed the cases, previous judgments notwithstanding, and found him guilty. This time, Altybay's perseverance paid

108. 1877nchī yilinda 13nchī jūzada Tāshkand ūyāzī-nīng hākimīgha Tāshkand ìchīda qūl āstī būlūb qarār qūlghuwchī qazāqiyyalārnīng kullan fuqarālārīdīn, TsGARUz, f. I-36, op. 1, d. $1214,1.13$.

109. Ego Vysokoblagorodiiu G. Nachal'niku g. Tashkenta, TsGARUz, f. I-36, op. 1, d. 1214, 1. 15, 23. See also an undated report most probably written by the assistant to City Commandant Bolozhevskii on the situation of the investigation ordered by von Kaufman in 1877, TsGARUz, f. I-36, op. 1, d. 1214, 1.31-32ob, and the final report on the investigation of the same case ordered by Military Governor Trotskii in May 1878, K dokladu: 27 aprelia 1878, TsGARUz, f. I-36, op. 1, d. 1214, 1. 24-25ob.

110. Cf. the sentences of the assembly of the Kurama biys (Qürāma $\bar{u} y \bar{a} z \bar{\imath} n \bar{\imath}$ siyāz biylārī), TsGARUz, f. I-36, op. 1, d. 1214, 1. 104, 105, 106.

111. Tāshkand hākimī Pūka-lūf-gha Tāshkand-da tūrghuwchi Qazāq Āltī Bāy Qul Biy ūghlīdān, TsGARUz, f. I-36, op. 1, d. 1214,1. 29.

112. 'Izzatlū wa hurmat-lū wa bīkmartaba-lū Turkistān wayānnāy Gūbirnāturī Tūrāt-īskī sīzn̄̄ng janābinḡ̄z-gha Tāshkand shahrī-n̄̄ng B̄̄sh Yaghāch būluwchī-nīng Qazāghī Āltī Bāy Biy Qul Biy ūghl̄-dān 'ariza, TsGARUz, f. I-36, op. 1, d. 1214, 1. 45ob-46. 
off: the general-governor annulled the judgment and Altybay's belongings were returned to him. ${ }^{113}$

As they had been told by the Kazakhs that they would prefer to be judged according to Islamic law and had been petitioned for so many cases of wrongdoing, the Russians thought that the community lacked anyone qualified to be elected to the position of judge. Contrary to expectations, the Kazakhs insisted on having a new biy and elected a person who had previously been favored by Altybay: Taybek Berdi-ughli. ${ }^{114}$

Taybek himself had a rough time while carrying out his duties. His career did not last one year. In the fall of 1880, three Kazakhs of the Kurama uezd were each robbed of a camel. They claimed to have seen the animals with a certain Balkut Shakurbay, a Kazakh from the city of Turkestan. At that time, Balkut was living in the Sibzar district. Accordingly, the three Kazakhs filed the lawsuit against Balkut in the presence of the aksakal of Sibzar, and Taybek was asked to hear the case. ${ }^{115}$ The investigation revealed that Balkut was guilty. Taybek then proposed the two parties should apply the qarindāsh, a legal mechanism in Kazakh customary law ( qazaq 'adadmīzga muwāfiq) which involves a mediation between the two parties in a dispute on the basis of kinship ties.116 Accordingly, it was ruled that the defendant pay a given sum of money, and all parties expressed their satisfaction with this agreement ( $\bar{l} k k \bar{\imath}$ taraf $\bar{u} \operatorname{sh} b \bar{u}$ bitīmga rāzi $b \bar{u} l \bar{u} b) .{ }^{117}$

As legal documents show, the lawsuit was brought to a satisfactory conclusion thanks to the use of local judicial customs. However, in March 1881 Balkut denounced Taybek to the Russian government, claiming that the biy had handcuffed him before the trial. The city commandant's assistant began an investigation. It turned out that when accused of robbery, Balkut became violent and declared to the aksakal that he intended to escape. Taybek had been asked to keep Balkut in custody, but fearing that the latter would flee to Turkestan before being prosecuted, he decided to take a precautionary measure and handcuffed him. Taybek was imprisoned and removed from office. ${ }^{118}$ The Russian administration could not but acknowledge that nobody in the Kazakh community deserved to be appointed to the post of biy. When the city commandant reported to the military governor, he held that the Kazakh contingent of Tashkent was made up of

113. Pomoshchnik Voennogo Gubernatora Syrdar'inskoi oblasti, ianvaria 1879 goda, TsGARUz, f. I-36, op. 1, d. 1214, 1. 47-48ob.

114. Gospodinu I.d. Voennogo Gubernatora Syrdar'inskoi oblasti, 25 ianvaria 1879 goda, TsGARUz, f. I-36, op. 1, d. 1214, 1.29; 1877nch̄̄ yilda [sic] 6nch̄̄ 'aqrābda Tāshkand hākīmnīng khizmatlārīgha rāpū [r]t, TsGARUz, f. I-36, op. 1, d. 1330,1. 44.

115. 1880nch̄̄ yil̄̄nda 27nchī jaddīda bizlār tūbānda tamghā sālghuwch̄̄, TsGARUz, f. I-36, op. 1, d. $1944,1.10$.

116. Kirgizskaia stepnaia gazeta..., op. cit., 764.

117. 1880nch̄̄ yilinda 27nch̄̄ jadd̄̄da bizlār tūbānda muhr bāsquwch̄̄, TsGARUz, f. I-36, op. 1, d. 1944,1. 11 .

118. Akt, TsGARUz, f. I-36, op. 1, d. 1944, 1. 4-6. 
renegades from other uezds who were individuals of disputable morality. ${ }^{119}$ Most probably, rumors were spread in Tashkent about the commandant's dissatisfaction and the arguments he had used in order to prevent the Kazakh community from electing a new judge. In fact, only two months later the Kazakhs petitioned the commandant in order to complain about the incorrect and improper behaviour of Taybek. In order to persuade him, they referred to the previous cases which had left the city commandant dissatisfied with the biy (Tāybīknīng khilāf nizām qīlgān janāblārīgha ma'lūm būlgān sabablì). Consequently, they went on to ask him to revise cases Taybek had previously closed (Tāybīkning qīlgān wa butūrgān ishlārīn haqīqat qūlūrgha farmāyish), thus proving that their commitment was serious, and only after this did they ask him to let them elect a new biy (biy qīlūb), chosen among reasonable and knowledgeable individuals of their community ( 'aqli $\bar{k} \bar{\imath} \mathrm{sh}$ bilādūrghān $\bar{a}$ damlārdīn). ${ }^{120}$ The request was accepted and in July 1881, the Kazakhs elected Yakhshibay Khudybay. ${ }^{121}$ But, as had happened before, Yakhshibay did not stay in office for long. At the beginning of 1882, he was anonymously accused of bribery.122

\section{Conclusion}

While Russian lawmakers may have thought of elections as a tool to undermine the native judiciary in Central Asia, this case study has shown that their strategy proved to be successful only with the biys, while the qadis' positions actually became more stable. As we noted above, in order to explain such a major difference, we have to assume that with the establishment of colonial power, the native judiciary (both qadis and biys) lost their former economic privileges. However, while the qadi could charge fees solely for drawing up marriage contracts, anyone holding the position of biy could count on quite a stable income which came from the fee he was entitled to charge (biylik) as well as from performing other duties such as that of tax collector.

In recent years, the perils and fluctuations associated with the post of judge in Central Asian 'a dat-based courts have become a topic of scholarly investigation. In this respect, it should be noted that $\mathrm{Ol}^{\prime}$ ga Brusina, relying on the notes prepared by Russian observers for the Girs' commission (1880-82), has emphasized the decay of authority among the biys, arguing that the election system allowed individuals who were not knowledgeable about customary law to become judges. ${ }^{123}$ If we follow this argument, we should infer that the instability suffered by the biys in Tashkent was the direct result of their ignorance on matters regarding 'a $\bar{a}$ dat: biys were removed because they were not qualified to hold the office they had been

119. Raport, TsGARUz, f. I-36, op. 1, d. 1944, 1. 6-7ob.

120. 1881nchī yilnda 19nchī māy āyinda 'arz-nāma, TsGARUz, f. I-36, op. 1, d. 1944,1. 18.

121. Kopiia. Gospodinu nachal'niku. G. Tashkenta, TsGARUz, f. I-36, op. 1 d. 1944, 1. 22.

122. TsGARUz, f. I-36, op. 1 d. 1944, 1. 24, 27-28.

123. Brusina, "Obychnoe pravo kochevogo naseleniia Turkestana..." art. cit., 225. 
elected to. On the contrary, from the cases we have studied, it seems that the biys' lack of knowledge and moral decay were issues which worried the Russians much more than the Kazakhs. In fact, from the very beginning of the establishment of Russian rule in Central Asia, colonial officers and administrators - especially those who claimed long experience of 'a dat-based court proceedings - were deeply concerned about the immorality of the biys. ${ }^{124}$ Therefore, it is highly likely that in an environment of emerging factionalism such as the tiny Kazakh milieu in Tashkent, local groups were "instrumentalizing" arguments such as the lack of legal knowledge, corruption, or financial misbehavior merely to influence the Russian governors' decisions in their favor. In fact, as the investigation of the cases involving the biys Altybay and Taybek has shown, the charges brought against them by their fellow Kazakhs were ultimately found to be groundless. This suggests that such arguments were used by the Kazakhs as discursive weapons in order to gain control of local judgeships: they voted for the person who in a given circumstance appeared to be the most trustworthy. But as soon as the biy they had elected ruled against them, they could always try to get rid of him by discrediting his moral standing or else questioning his ability to judge.

In addition, the reliability of the conclusions made by Russian experts should not be taken for granted or trusted more than the indigenous complaints. That this may indeed be so is clear when we examine the accounts given by the local people who were heard by the Girs' commission. Among many other issues concerning the native administration, the deleterious effects of holding elections were directly discussed by aksakals, qadis, and notables from Turkestan, that is, a group which included representatives of the Tashkent and Kurama uezds. Everybody acknowledged that because of the elections, administrative posts were sometimes occupied by individuals who were not suitable (nā-munāsib) to carry out the duties involved. They could not hide that election results could depend on corruption ( $p u l$, pāra), moral suasion (ri '⿳亠丷厂彡ya), and threats (ighwālār). ${ }^{125}$ Despite these problems, they emphasized that trustworthy, qualified people were still elected. When asked about the duties of qadis and biys, the judiciaries from both the settled and the nomadic population strongly recommended that qadis should be allowed to participate in elections only if given a letter of recommendation (shahädat-nāma) by the 'ulama $\bar{a}$ ' and the faculty of the city madrasas. ${ }^{126}$ But when they touched upon the nomadic groups and their judiciary, the Kazakhs asked the colonial administration that "for the sake of the Kazakh population, a biy should be elected in every volost ' in order to decrease the number of disputes."127

124. See for example, N. Dingel'shtadt, "Odno iz otzhivaiushchikh uchrezhdenii," Zhurnal grazhdanskago i ugalovnago prava, 7 (1892): 1-23; A.Zuev, "Kirgizskii narodnyi sud," Zhurnal ministerstva iustitsii, 12 (1907): 161-208.

125. Cf. Sbornik otvetov, ms. Tashkent, Institute of Oriental Studies, Academy of Sciences, inv. no. 1644/II, f. $7^{\mathrm{v}}, 14^{\mathrm{r}}, 39^{\mathrm{r}}$.

126. Ibid., f. $40^{\mathrm{r}}$.

127. wa yana iltimās qūlāmīz qazaqiyya fuqarālārn̄̄ manfa'at̄̄ ūchūn har bir būlūstgā $\bar{\imath} k k \bar{\imath}$ nafardan biy qūlinsa aning ūchūnki mazkūrlārn̄̄ janjāllārı̄ kam būlūb, ibid., f. 40r. 
Although the case of the Tashkent Kazakhs is, of course, a particular one, it furnishes relevant information on how important it was for a community to keep alive the practice of customary law in a colonial environment which was deliberately trying to undermine the credibility of its judiciary. What is apparent from the examples we have provided is that, even if they were subjected to instability and their authority was suspect in the eyes of the Russian administrators, the biys were still deemed as essential for defining the rights and the obligations of Tashkent's Kazakh community. Moreover, as the position of biy was still regarded with respect and was economically appealing, elections may have only intensified factionalism, which had already existed in pre-colonial time, and can still be seen in the regions of modern Central Asia where elections were never introduced. ${ }^{128}$

Orientalisches Institut der

Martin-Luther-Universität Halle-Wittenberg

paolo.sartori@orientphil.uni-halle.de

128. Stéphane A. Dudoignon, "Les 'tribulations' du juge Ziya. Histoire et mémoire du clientélisme politique à Boukhara (1868-1929),” Annales H. S. S., 59, 5-6 (2004): 1095-1135. 